\title{
Karakteristike financijskog posredovanja banaka po hrvatskim županijama
}

Krišto, Jakša; Mandac, Iva

Source / Izvornik: Odabrani prijevodi, 2015, 6, 1 - 19

Journal article, Published version

Rad u časopisu, Objavljena verzija rada (izdavačev PDF)

https://doi.org/10.3326/op.28

Permanent link / Trajna poveznica: https:/urn.nsk.hr/urn:nbn:hr:242:167997

Rights / Prava: Attribution-NonCommercial-NoDerivatives 4.0 International/ImenovanjeNekomercijalno-Bez prerada 4.0 međunarodna

Download date / Datum preuzimanja: 2023-04-26

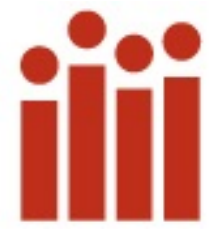

Institute of Public Finance Repository

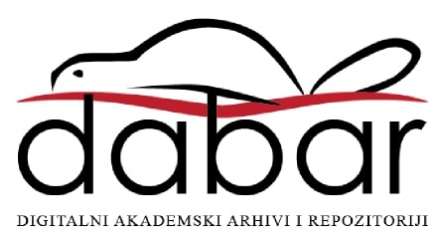


Institut za

javne financije

Smičiklasova 2I | Zagreb

www.ijf.hr | ured@ijf.hr

T: oI/4886-444 | F: OI/48I9-365

\section{PRIJEVODI}

ISSN I847-7445

\section{BR. 28/15}

citirati: Krišto, J. i Mandac, I. 2015. Characteristics of bank financial intermediation in Croatian counties. Financial Theory and Practice, 39 (I), str. 57-82.

http://www.fintp.hr/upload/files/ft p/2015/I/kristo_mandac.pdf

Svi Odabrani prijevodi dostupni su na: http://www.ijf.hr/hr/publikacije/ca sopisi/I2/odabrani-prijevodi/III/

\section{KARAKTERISTIKE FINANCIJSKOG POSREDOVANJA BANAKA PO HRVATSKIM ŽUPANIJAMA}

\author{
DR. SC. JAKŠA KRIŠTO* \\ ČLANAK $^{* *}$ \\ UNIV.BACC.OEC. IVA MANDAC \\ JEL: G2I, OI6, OI8 \\ DOI: $10.3326 /$ op.28
}

\section{SAŽETAK}

Istraživanja na temu financijske intermedijacije banaka na užim teritorijalnim jedinicama pojedine države deficitarna su kako u domaćoj, tako i stranoj literaturi. Banke su gotovo isključive institucije financijskog posredovanja na užim teritorijalnim jedinicama, a njihova je uloga izražena, od sudjelovanja u regionalnom razvoju do uspješnosti vlastitog poslovanja. Slijedom navedenoga, osnovni cilj rada je preispitati karakteristike financijske intermedijacije banaka po županijama u Hrvatskoj, kako u dijelu usporedbe ekonomske razvijenosti i opće zastupljenosti financijskog posredovanja, tako i uže promatrajući karakteristike depozitne $i$ kreditne politike. U radu se koristi metodologija hijerarhijske $i$ nehijerarhijske $k$-means klaster analize u identifikaciji relativno homogenih skupina županija promatranih na skupinama pokazatelja za ekonomsko okruženje, financijsku razvijenost $i$ infrastrukturu te detaljnije depozitnu $i$ kreditnu politiku banaka. Rezultati istraživanja ukazuju na heterogenost $i$ raznolikost bankovne politike po županijama, kao i po skupinama pokazatelja. Ističu se razlike između razvijenih i nerazvijenih županija te u pristupu depozitnoj i kreditnoj bankovnoj poslovnoj politici. Nalazi u radu potiču i usmjeravaju na daljnja istraživanja.

Ključne riječi: financijsko posredovanje i poslovna politika banaka, županije, Hrvatska, klaster analiza
Autori zahvaljuju dvojici anonimnih recenzenata na korisnim sugestijama koje su pridonijele poboljšanju članka.

Primljeno: 15. srpnja 2014.

Prihvaćeno: II. studenog 2014.

\section{Jakša KRIŠTO}

Ekonomski fakultet u Zagrebu, Trg J. F. Kennedyja 6, Ioooo Zagreb e-mail: jkristo@efzg.hr

Iva MANDAC

Croatia banka d.d., Roberta Frangeša Mihanovića 9, Ioooo Zagreb

e-mail: iva.mandac@gmail.com 


\section{UVODNE NAPOMENE}

Važnost, doprinos i utjecaj financijske intermedijacije banaka na ekonomski rast i razvoj je predmet brojnih istraživanja i teorijskih shvaćanja koja se kreću od nepostojanja izražene veze, neutralne uloge, do značajnog utjecaja na ekonomski rast. Financijska intermedijacija banaka na regionalnoj razini podzastupljena je $\mathrm{u}$ istraživanjima doprinosa regionalnom ekonomskom rastu i razvoju. Poslovne banke, kao financijske institucije u privatnom ili državnom vlasništvu, za cilj svog poslovanja opravdano postavljaju maksimizaciju bogatstva dioničara, a problematika regionalnog razvoja i ujednačavanja razvijenosti regija prepuštena je usmjerenoj regionalnoj politici države. U tradicionalnom europskom i nerazvijenijim bankovno utemeljenim financijskim sektorima, banka je dominantna institucija financijskog posredovanja, a ukoliko se promatra na užim teritorijalnim jedinicama banke su najvažnije institucije financijskog posredovanja. Navedenom doprinosi i visoka centralizacija financijskih tokova oko većih financijskih centara i financijskih tržišta. Regionalna dimenzija financijske intermedijacije banaka očituje se primarno u učinkovitoj kreditnoj politici, prikupljanju depozita, obavljanju ostalih financijskih usluga i pružanju financijskog servisa. Regionalna poslovna politika banaka povezana je s ukupnom poslovnom strategijom banke, geografskom ekspanzijom poslovnica, ulaganjem u bankovnu infrastrukturu, informacijskim tehnologijama, financijskom isključenosti, profitabilnosti pojedinih užih teritorijalnih jedinica, regulatornim okvirom te ostalim poslovnim odrednicama i odrednicama same uže teritorijalne jedinice. Sveobuhvatne karakteristike i važnost bankovnog poslovanja nameću potrebu preispitivanja bankovne politike na užim teritorijalnim jedinicama neke države.

Osnovni je cilj rada preispitati financijsku intermedijaciju banaka po županijama u Hrvatskoj u dijelu: usporedbe s ekonomskom razvijenošću, razmjera financijske intermedijacije te karakteristika depozitne i kreditne politike banaka. Cilj je statističke analize identificirati relativno homogene skupine županija promatrane kroz četiri skupine pokazatelja kako bi se dobila slika o teritorijalnoj distribuciji i (među)ovisnosti različitih karakteristika financijske intermedijacije banaka i ekonomskog okruženja. $U$ radu se koristi deskriptivna statistika u analizi formiranih pokazatelja te hijerarhijska i nehijerarhijska $k$-means metoda klaster analize. Prema saznanjima autora, ovo je prvi rad u Hrvatskoj koji analizira sektorsko financijsko posredovanje banaka i općenito poslovanje nekih od financijskih institucija na razini županija u Hrvatskoj. Rezultati ovakvog pristupa i šireg istraživanja mogu potencijalno biti korisni u oblikovanju regionalne ekonomske politike, ali i ukazati na tržišne potencijale i prostor za oblikovanje usmjerenije bankovne poslovne politike na razini županija Hrvatske.

Rad je podijeljen u pet dijelova. Nakon uvodnih napomena, u drugom dijelu prikazan je širi pregled strane i domaće literature koja se odnosi na problematiku financijskog posredovanja banaka na užim regionalnim područjima. U trećem dijelu prikazani su podaci i metodologija istraživanja, a u četvrtom izloženi rezultati istraživanja i interpretacija te rasprava o rezultatima. Na kraju, u zaključku su izloženi ključni nalazi rada i preporuke za daljnja istraživanja.

\section{Pregled litterature}

Tema rada je multidisciplinarna i obuhvaća različita područja, od poslovne politike banaka do problema financijske intermedijacije i poveznice s regionalnim rastom. Inozemna literatura navodi kako manjka istraživanja utjecaja financijskog posredovanja na regionalni razvoj (Rodriguez-Fuentes, I996.; Dow, 1987.; Crocco et al., 20IO.; Burgstaller, 2013.). Navedeno je izraženo zbog ograničene 
dostupnosti podataka, ali i teoretskih shvaćanja neutralnosti novca i financijske intermedijacije u postizanju ekonomskog rasta. Međunarodna i domaća istraživanja relevantna za ovaj rad mogu se prema području podijeliti na grupe istraživanja o:

I) važnosti financijske intermedijacije banaka za ekonomski rast i uže utjecaj financijske intermedijacije banaka na regionalni razvoj,

2) teritorijalnoj poslovnoj politici banaka i strategiji banaka po pojedinim bankovnim djelatnostima,

3) uspješnosti ekonomskih politika u regionalnom razvoju i smanjenju regionalnih nejednakosti te optimalnoj regionalnoj podjeli na uže teritorijalne jedinice.

Prva grupa radova, proučavajući važnost financijske intermedijacije banaka za ekonomski rast temeljito je istraživana u većoj mjeri na razini različitih država i financijskih sustava. Istaknutija istraživanja na ovu temu proveli su Allen i Gale (1999.), Levine (2002.), Demirgüç-Kunt i Levine (200I.), Arestis et al. (2005.). Levine je iznio jedan od dokaza da je struktura i vrsta financijskog sektora nevažna i nema utjecaja na ekonomski rast. Niti bankovno orijentirani (engl. bank-based), u pravilu usmjereni dominantno na financijsku intermedijaciju putem banaka, ni tržišno orijentirani (engl. market-based) financijski sustavi, orijentirani na financijsko posredovanje putem financijskog tržišta, ne mogu se dovesti u isključivu vezu s ekonomskim rastom. Umjesto toga, pokazalo se da je za ekonomski rast bitan ukupan značaj financijskih usluga, banaka i financijskih tržišta zajedno. Zaključke iznosi koristeći ekonometrijsko testiranje regresijskim modelima rasta (Levine, 2002.).

Bađun (2009.) je provela temeljiti prikaz i analizu istraživanja na temu utjecaja financijske intermedijacije banaka na ekonomski rast. U radu prikazuje i navodi zaključke istraživanja, kako onih o pozitivnom utjecaju razmjera financijske intermedijacije na ekonomski rast, tako i onih koji ne pronalaze značajniju povezanost. Zaključuje kako je uz prevladavajući stav o pozitivnom utjecaju financijske intermedijacije banaka na ekonomski rast potrebno provesti dodatna istraživanja i napore usmjeriti u proučavanje odnosa banaka i države (Bađun, 2009.).

Valverde et al. (2007.) istraživali su utjecaj financijske intermedijacije na ekonomski rast na teritorijalnim jedinicama - regijama Španjolske. Naglašavaju kako je pristup ovakvoj analizi po regijama jedne države relevantniji budući su regionalni podaci homogeniji, pravni i zakonski okvir je jednak, a financijski sustav jednoznačno definiran i postavljen. Rezultati do kojih su došli u provedenom istraživanju koristeći metodologiju dinamičkih panela na primjeru regija u Španjolskoj potvrđuju pozitivnu i signifikantnu vezu između produbljenosti bankovnog posredovanja i regionalnog rasta (Valverde et al., 2007.). Rodriguez-Fuentes (1998.) prikazuje različite pristupe shvaćanju utjecaja bankovnog poslovanja na regionalni razvoj. Naglašava kako su monetarne i financijske varijable i njihov utjecaj na regionalni ekonomski razvoj često isključeni iz radova na temu regionalne politike, kako zbog uvažavanja shvaćanja neutralnosti monetarne politike za ekonomski rast i nepostojanja instrumenta monetarne politike na regionalnoj razini, tako i zbog pretpostavke o savršenoj otvorenosti tržišta i mobilnosti kapitala. Zaključuje, koristeći model jednostavne linearne regresije, da banke ipak mogu kroz dostupnost kredita utjecati na regionalni razvoj.

Značajan doprinos proučavanju financijskog posredovanja i regionalnog razvoja dala je Dow proučavajući utjecaj monetarnih varijabli i financijskog posredovanja na regionalni razvoj. Dow (1987a) sveobuhvatnim prikazom i analizom različitih teorijskih pristupa i usmjerenja zaključuje kako monetarna politika i financijske institucije imaju aktivnu ulogu u neravnomjernom regionalnom 
razvoju. Naglašava kako je neravnomjeran regionalni razvoj posljedica čitavog niza ekonomskih politika i utjecaja, između kojih se ne može isključiti novac i bankovno posredovanje. Sjedišta banaka koja su u financijskim središtima utječu na poteškoće u pozajmljivanju financijskih sredstava poslovnih subjekata u drugim regijama, dok stanovništvo i poduzeća u nerazvijenim regijama imaju veću preferenciju likvidnosti. Ukazuje kako i nerazvijene regije preferiraju štednju i održavanje likvidnosti u financijskim centrima čime dodatno, uz slabiju dostupnost kredita, slabe svoju financijsku poziciju. Ističe i razlike između regionalno specifičnih banaka i poslovnica banaka iz financijskih središta u upravljanju likvidnošću, kreditnoj politici i ulaganju u vrijednosne papire (Dow, I987a).

Crocco et al. (20Io.) analiziraju različitosti u regionalnoj strategiji banaka u gospodarstvu Brazila. Dokazuju analizom vlastitih kreiranih pokazatelja temeljenih na računovodstvenim podacima o bankovnom poslovanju da je strategija banaka u bankovnom sustavu Brazila heterogena po regijama i da takav pristup banaka pospješuje nejednakost u regionalnom razvoju. Fernandez de Guevara i Maudos (2009.) analiziraju i matematički modeliraju utjecaj regionalnog financijskog razvoja i bankovne konkurencije na rast kompanija na primjeru španjolskih županija (NUTS ${ }^{\mathrm{I}}$ 3). Zaključuju kako kompanije s izraženijim inozemnim financiranjem $u$ financijski razvijenijim županijama rastu brže. Burgstaller (2013.) analizira, koristeći prostornu regresijsku analizu, bankovnu penetraciju, tržišnu strukturu i bankovno poslovanje po županijama Austrije. Dokazuje kako niže razvijene županije karakterizira viša stopa zaduživanja i niža stopa štednje, dok bankovna koncentracija ne utječe na županijske razlike u kamatnim stopama, profitabilnost niti učinkovitost banaka. Naglašava važnost poticanja ravnomjerne i pravedne bankovne pokrivenosti prostora županija. Colombo i Turati (20I4.) dokazuju snažan i direktan učinak ekonomskih i socijalnih karakteristika NUTS 2 regija na koncentraciju bankovne industrije u Italiji, kao i aglomeraciju pripojenih banaka u visoko razvijenim regijama. Koriste metodologiju probit i count data modela.

Druga skupina radova orijentirana je na geografski aspekt bankovne poslovne politike i problem financijske isključenosti. Literatura koja proučava poslovanje banaka ne pridaje preveliku važnost užim regionalnim specifičnostima poslovne politike banaka. Radovi su zastupljeni u dijelu geografije bankovnog poslovanja, informacijskih tehnologija, prostorne cjenovne diskriminacije, problema asimetričnih informacija i sl. (pogledati u Allesandrini et al., 2005.; Allesandrini et al. (ed.), 2009.).

Degryse i Ongena (2005.) na temelju podataka iz kreditnih ugovora velike belgijske banke nizom višestrukih regresijskih analiza s i bez dummy varijabli proučavaju utjecaj geografske udaljenosti na kamatne stope na kredite, uzimajući u obzir udaljenost između komercijalnog dužnika i njegove banke te između komercijalnog dužnika i druge konkurentske banke. Na uzorku od preko I5 tisuća kredita, pretežno malim poduzećima, uočavaju značajan porast kamatnih stopa na kredite s porastom udaljenosti između dužnika i konkurentskih banaka te inverzno kretanje troškova uzajmljenih sredstava i udaljenosti poduzeća od banke kreditora. Zaključuju kako su transportni troškovi, a ne asimetrične informacije, vjerojatno glavni izvor prostorne cjenovne diskriminacije.

Problematiku financiranja regionalnog razvoja kao jednog od ciljeva od javnog interesa ističe Leko (20II.). Prikazuje sustavne pristupe financiranju svih namjena od javnog interesa posredstvom različitih modela, tehnika i instrumenata koji uključuju državu, specijalizirane državne financijske

\footnotetext{
${ }^{\text {I}}$ Hrvatski pojam "Nomenklatura prostornih jedinica za statistiku” (NUTS) je statistička klasifikacija koja služi za prikupljanje, obradu, analizu i publiciranje statističkih prostornih podataka na razini Europske unije.
} 
institucije, ali i financijske institucije u privatnom vlasništvu te financijsko tržište. Ravnopravna regionalna poslovna politika banaka zastupljena je i direktno povezana s problematikom financijske isključenosti te svjesnim zanemarivanjem određenih neprofitabilnijih ili rizičnijih teritorijalnih područja ili skupina stanovništva od strane privatnih poslovnih banaka (više u Leko i Stojanović, 2OII.).

Treću skupinu radova predstavljaju domaći radovi iz problematike regionalne politike, najzastupljeniji u dijelu optimalne regionalne podjele na županije, kao i statističke podjele na NUTS 2 regije ili kritika regionalne podjele Republike Hrvatske (Lovrinčević et al., 2005.; Kurnoga Živadinović, 2007.; Žuljić, 20II.; Rašić Bakarić, 2005. i 2012.). U glavnini radova korištena je metodologija multivarijatne statističke analize u pravilu klaster analize. Zastupljeni su i radovi iz područja lokalnih financija, na temu fiskalnog izravnavanja i smanjivanja nejednakosti između općina i gradova, sustava financiranja gradova i pitanja decentralizacije u gradovima, lokalnih proračuna, fiskalnih odnosa između više razina vlasti i fiskalne decentralizacije (više u Rašić Bakarić et al., 20I4.). Problematiku regionalnog razvoja u Hrvatskoj analizirali su brojni radovi, kao na primjer Baletić et al. (1999.), Čavrak (2002., 2003. i 2012.), Puljiz (2009.), i dr. U navedenim domaćim istraživanjima nisu korištene varijable i podaci o financijskom posredovanju na razini županija te je segment financijskih institucija i tržišta izostavljen iz navedenih analiza. Jedan od razloga je i $\mathrm{u}$ ograničenoj dostupnosti podataka $\mathrm{u}$ objavljenim statističkim publikacijama koje još uvijek ne prate poslovanje financijskih institucija na razini užih teritorijalnih jedinica Hrvatske.

\section{PODAGI I METODOLOGIJA ISTRAŽIVANJA}

Cilj statističke analize je identificirati relativno homogene skupine županija promatrano kroz četiri skupine pokazatelja kako bi se dobila slika o teritorijalnoj distribuciji i (među)ovisnosti karakteristika ekonomskog okruženja, razvijenosti financijske intermedijacije te kreditne i depozitne bankovne politike. U tu svrhu primijenjen je sljedeći metodološki pristup:

I) na širem skupu od 23 pokazatelja odabrano je I7 pokazatelja koji su oblikovani u četiri skupine pokazatelja,

2) na podacima je provedena deskriptivno statistička analiza,

3) obavljena je standardizacija podataka za potrebe klaster analize primjenom standardizirane vrijednosti $z$,

4) provedena je hijerarhijska klaster analiza za skupine pokazatelja s uključenim Gradom Zagrebom i bez uključenog Grada Zagreba,

5) provjerena je robusnost rezultata primjenom druge mjere udaljenosti,

6) slijedom broja dobivenih klastera hijerarhijskom analizom te utvrđivanja netipičnih vrijednosti provedena je nehijerarhijska $k$-means klaster analiza, i

7) statistički i ekonomski su obrađeni rezultati te su naglašena ograničenja istraživanja i dane preporuke daljnjih istraživanja.

Dvadeset županija i Grad Zagreb (nadalje županije) analizirano je kroz I7 pokazatelja grupiranih u četiri skupine koje predstavljaju: (I) ekonomsko okruženje, (2) financijsku razvijenost i infrastrukturu, (3) depozitnu politiku banaka, i (4) kreditnu politiku banaka. Pojedinačni pokazatelji po grupama pokazatelja predstavljaju primjenjivane pokazatelje koji se koriste u mjerenju ekonomskog razvoja, stupnja financijskog posredovanja i poslovne politike banaka ili su kreirani kako bi se uvažile specifičnosti podataka i bankovnog posredovanja u Hrvatskoj. Svi pokazatelji odnose se na 201 . godinu, budući je uslijed ograničene dostupnosti podataka 20II. jedina godina i najnovije vremensko 
razdoblje u kojoj se preklapaju svi podaci. Izabrana istraživanja u Hrvatskoj provedena na užim teritorijalnim jedinicama koristeći multivarijatnu statističku analizu, također su koristila podatke za jednu godinu (Lovrinčević et al., 2005.; Rašić Bakarić, 2005.; Kurnoga Živadinović, 2007.; Rašić Bakarić, 2012.).

Pokazatelji bankovnog poslovanja pribavljeni su na pismeni zahtjev od Hrvatske narodne banke. ${ }^{3}$ Osim pokazatelja bankovnog poslovanja pribavljenih od HNB-a, koji čine glavninu podataka za provedenu analizu, dio podataka pribavljen je iz publikacija i internetskih stranica Državnog zavoda za statistiku i Hrvatskog zavoda za zapošljavanje. Dok su neki pokazatelji korišteni u analizi eksplicitno dani, dio pokazatelja formiran je stavljajući u odnos prikupljene podatke. Odabir pokazatelja unutar skupine pokazatelja bio je vođen teorijskom podlogom, ali i odabirom pokazatelja nižeg stupnja međusobne koreliranosti. Pri tome su odabrani pokazatelji čiji su koeficijenti korelacije niži od o,7, a koeficijent korelacije veći od navedenog, a manji od o,8 zabilježen je samo kod dva slučaja.

Deskriptivna statistička analiza na korištenim pokazateljima provedena je u MS Office Excel programu, a rezultati su prikazani u tablici I. Deskriptivnom analizom uočena je velika raznolikost županija promatrano kroz četiri skupine pokazatelja. Koeficijent varijacije broja stanovnika iznosi čak preko $80 \%$. Disperzija podataka o neto plaći je mala, ali srednje vrijednosti BDP-a po stanovniku i stope nezaposlenosti nisu reprezentativne. Iz pokazatelja udjela investicija u dugotrajnu imovinu namijenjenih financijskoj djelatnosti i djelatnosti osiguranja u BDP-u uočava se iznimno velika razlika među županijama u smislu financijske razvijenosti i infrastrukture. Najmanja vrijednost iznosi o,oı\%, a najveća čak 3,2\%. Svi ostali pokazatelji iz ove skupine potvrđuju regionalne disparitete. Raspon varijacije depozita po stanovniku iznosi 93 tisuće kuna, što upućuje na relativno veliku teritorijalnu nejednakost karakteristika depozitne politike. Ipak, depozitne poslove banaka s aspekta valutnih obilježja ne karakterizira prostorni disparitet. Promatrajući pokazatelje udio loših kredita u ukupnim kreditima, udio kredita u eurima u ukupnim kreditima te udio stambenih kredita $\mathrm{u}$ ukupnim kreditima stanovništva nameće se relativna teritorijalna konzistentnost kreditne politike. Istovremeno, promatrano kroz pokazatelje udio kredita kućanstvima u ukupnim kreditima te udio kredita u švicarskim francima u ukupnim kreditima, raspršenost podataka oko srednje vrijednosti je značajna. Teritorijalna konzistentnost valutnih karakteristika depozitne i kreditne politike mjerena nižim iznosom koeficijenta varijacije potvrđuje visoki udjel i relativno ravnomjernu rasprostranjenost dolarizacije (euroizacije) u hrvatskom bankovnom sustavu.

\footnotetext{
${ }^{2}$ Državni zavod za statistiku objavio je na svojoj Internet stranici I4. veljače 20I4. podatke o BDP-u po županijama Hrvatske za 20II. godinu.

${ }^{3}$ Podaci o imovini i bruto kreditima odnose se na protustranke iz Hrvatske sa sjedištem ili prebivalištem u županiji. Kod određenih županija neto imovina banaka niža je od iznosa bruto kredita. Ovo odstupanje uzrokovano je time što je iznos imovine banaka dan u neto knjigovodstvenom iznosu (umanjeno za ispravke vrijednosti), dok su podaci o kreditima dani u bruto knjigovodstvenom iznosu kako bi se mogli na adekvatan način koristiti u izračunu pokazatelja kvalitete kredita. Dani krediti (neto) u prosjeku (aritmetička sredina) čine 94\% imovine jedne županije. Raspored protustranaka (njihova sjedišta odnosno prebivališta) po županijama obavlja se na osnovi popisa kojeg Hrvatska pošta d.d. objavljuje na svojoj internetskoj stranici. No, postoje određeni instrumenti (poput gotovine, goodwilla, općih rezervi za rizičnu skupinu A, i dr.), gdje je banka u obvezi samu sebe iskazati kao protustranku. Stoga su ti instrumenti iskazani na županijama sjedišta banke. Osim toga, pojedini su instrumenti (poput depozita kod Hrvatske narodne banke) iskazani u cijelosti na jednoj županiji, što je u spomenutome slučaju Grad Zagreb (HNB, 2OI4.).
} 
TABLICA I.

Rezultati deskriptivne statističke analize po skupinama pokazatelja po županijama

\begin{tabular}{|c|c|c|c|c|c|c|c|}
\hline $\begin{array}{l}\text { Skupina } \\
\text { pokazatelja }\end{array}$ & Pokazatelj & Prosjek & Medijan & $\begin{array}{c}\text { Standardna } \\
\text { devijacija }\end{array}$ & Min. & Max. & $\begin{array}{c}\text { Koeficijent } \\
\text { varijacije, u \% }\end{array}$ \\
\hline \multirow{4}{*}{$\begin{array}{l}\text { Ekonomsko } \\
\text { okruženje }\end{array}$} & $\begin{array}{l}\text { Bruto domaći proizvod po } \\
\text { stanovniku, u tisućama } \\
\text { kuna (popis stan. 2OII.) }\end{array}$ & 76,8 & 6o,I & 24,5 & 43,7 & I37,6 & 32,0 \\
\hline & Neto plaća, u kunama & 5.014 & 4.985 & 440 & 4.380 & 6.359 & 8,8 \\
\hline & Stanovništvo, u tisućama & 204,0 & 158,3 & 165,5 & 50,7 & 790,9 & $8 \mathrm{I}, 2$ \\
\hline & Stopa nezaposlenosti, u \% & 22,4 & 22,3 & 7,0 & 9,4 & 33,8 & $3 \mathrm{I}, 4$ \\
\hline \multirow{5}{*}{$\begin{array}{l}\text { Financijska } \\
\text { razvijenost i } \\
\text { infrastruktura }\end{array}$} & Neto imovina/BDP, u \% & II2,I & 69,6 & 0,4535 & 52,0 & 187,3 & 40,5 \\
\hline & $\begin{array}{l}\text { Broj stanovnika na i } \\
\text { poslovnicu, u tisućama }\end{array}$ & 3,4 & 3,3 & $\mathrm{I}, \mathrm{I}$ & $\mathrm{I}, \mathrm{I}$ & 6,0 & 33,8 \\
\hline & $\begin{array}{l}\text { Broj stanovnika na I } \\
\text { bankomat, u tisućama }\end{array}$ & $\mathrm{I}, \mathrm{I}$ & $\mathrm{I}, 4$ & 0,6 & 0,3 & 2,2 & 52,8 \\
\hline & $\begin{array}{l}\text { Imovina banaka per capita, } \\
\text { u tisućama kuna }\end{array}$ & 86,0 & $4 \mathrm{I}, 3$ & 57,7 & 29,8 & 257,6 & 67,1 \\
\hline & $\begin{array}{l}\text { Investicije u novu } \\
\text { dugotrajnu imovinu } \\
\text { namijenjene financijskoj } \\
\text { djelatnosti i djelatnosti } \\
\text { osiguranja/BDP, u \% }\end{array}$ & $\mathrm{I}, 2$ & $\mathrm{O}, \mathrm{I}$ & O,OIII & O,OI & 3,2 & 94,0 \\
\hline \multirow{3}{*}{$\begin{array}{l}\text { Depozitna } \\
\text { politika }\end{array}$} & Krediti/depoziti & $\mathrm{I}, 28$ & $\mathrm{I}, 36$ & 0,3730 & 0,79 & 2,07 & $29, I$ \\
\hline & $\begin{array}{l}\text { Depoziti po stanovniku, } \\
\text { u tisućama kuna }\end{array}$ & 52,8 & $3 \mathrm{I}, 3$ & 26,2 & $\mathrm{I} 7,4$ & IIO,4 & 49,6 \\
\hline & $\begin{array}{l}\text { Devizni depoziti u } \\
\text { ukupnim depozitima, u \% }\end{array}$ & 66,6 & 68,7 & o,0629 & 59,2 & 78,7 & 9,4 \\
\hline \multirow{5}{*}{$\begin{array}{l}\text { Kreditna } \\
\text { politika }\end{array}$} & $\begin{array}{l}\text { Udio kredita kućanstvima } \\
\text { u ukupnim kreditima, u \% }\end{array}$ & 44,0 & 60,3 & O,I543 & $27, \mathrm{I}$ & $72, \mathrm{I}$ & $35, \mathrm{I}$ \\
\hline & $\begin{array}{l}\text { Udio kredita u CHF u } \\
\text { ukupnim kreditima, u \% }\end{array}$ & IO,9 & $\mathrm{I} 3,2$ & $\mathrm{O}, 043 \mathrm{I}$ & 7,3 & 22,7 & 39,5 \\
\hline & $\begin{array}{l}\text { Udio kredita u EUR u } \\
\text { ukupnim kreditima, u \% }\end{array}$ & 63,6 & 58,5 & 0,0562 & 54,3 & 69,3 & 8,8 \\
\hline & $\begin{array}{l}\text { Udio loših kredita u } \\
\text { ukupnim kreditima, u \% }\end{array}$ & $\mathrm{I} 2,4$ & $\mathrm{I} 3,4$ & O,O219 & IO,9 & $\mathrm{I} 7,8$ & $\mathrm{I} 7,7$ \\
\hline & $\begin{array}{l}\text { Udio stambenih kredita } \\
\text { u ukupnim kreditima } \\
\text { stanovništva, u \% }\end{array}$ & 49,3 & 43,2 & O,098I & 32,3 & 59,0 & I9,9 \\
\hline
\end{tabular}

Izvor: izrada autora.

Pri provođenju klaster analize potrebno je voditi računa o mjernim jedinicama varijabli. Ako su one različite, bilo koja mjera udaljenosti djelovat će na doprinos varijabli mjerenih većim mjernim jedinicama, stoga je standardizacija podataka za potrebe analize provedena primjenom standardizirane vrijednosti $z$, čime se odstupanja vrijednosti varijable od njezine srednje vrijednosti izražavaju u jedinicama standardne devijacije.

S ciljem klasifikacije hrvatskih županija kao jedinica promatranja u veće i s obzirom na promatrane karakteristike homogenije prostorne cjeline, korištena je početno hijerarhijska metoda klaster analize. Hijerarhijske metode klaster analize karakterizira razvijanje hijerarhije, a razlikuju se aglomerativne i metode podjele. U radu je korištena aglomerativna metoda koja se sastoji od 4 osnovna koraka (Rašić Bakarić, 20Io.):

I) Algoritam započinje $\mathrm{s} n$ klastera, svaki klaster sadrži jedan objekt te simetričnu matricu udaljenosti reda $n \times n, D=\left[d_{i k}\right]$. 
2) Unutar matrice udaljenosti traži se najbliži (najsličniji) par klastera. Neka se udaljenost između “najsličnijih" klastera U i V označi s $d_{U V}$.

3) Klasteri U i V se spajaju te se ponovno izračunavaju elementi matrice udaljenosti i to na način da se brišu reci i stupci koji odgovaraju klasteru U i V te dodaju reci i stupci u kojih su elementi vrijednosti udaljenosti između klastera UV i preostalih klastera.

4) Koraci 2 i 3 ponavljaju se $n$-I puta. Na kraju rada algoritma, svi će se objekti nalaziti u jednom klasteru.

Korištena je Wardova metoda varijance koja klastere formira na osnovi minimiziranja varijance unutar klastera. Wardova se metoda temelji na izračunu gubitka informacija do kojeg dolazi pri grupiranju objekata u klastere, a karakterizira ju primjena kvadrirane euklidske udaljenosti koja udaljenost među objektima izražava kao zbroj kvadriranih razlika između vrijednosti objekata:

$$
u_{A B}=\sum_{i=1}^{v}\left(A_{i}-B_{i}\right)^{2} .
$$

Wardova metoda udaljenosti između dva klastera izražava prema sljedećem:

$$
u_{A B}=\frac{\left|\bar{x}_{A}-\bar{x}_{B}\right|^{2}}{\frac{1}{N_{A}}+\frac{1}{N_{B}}}
$$

gdje je $\bar{x}_{A}$ sredina klastera $\mathrm{A}, \bar{x}_{B}$ sredina klastera $\mathrm{B}, N_{A}$ broj objekata u klasteru A te $N_{B}$ broj objekata $\mathrm{u}$ klasteru B. Pri provođenju Wardove metode za svaki se klaster računaju sredine svih varijabli. Zatim se za svaki klaster računa kvadrirana euklidska udaljenost sredina klastera i te se udaljenosti zbrajaju za sve objekte. S porastom broja formiranih klastera raste i ukupan zbroj kvadrata odstupanja. Pri svakom se koraku kombiniraju dva klastera čijim spajanjem dolazi do najmanjeg porasta ukupnog zbroja kvadriranih euklidskih udaljenosti unutar novog klastera (Kurnoga Živadinović, 2007.).

Rezultati hijerarhijske klaster analize grafički su prikazani dendrogramom. Iako nema strogog pravila i često je predmet preispitivanja, broj klastera prema hijerarhijskoj analizi može se odrediti korištenjem cut-off vrijednosti, bilo putem omjera nekonzistentnosti ili kriterija zasnovanog na udaljenosti (Halaj i Zochowski, 2009.). Kurnoga Živadinović (2007.) nudi nekoliko smjernica za određivanje broja klastera s obzirom da hijerarhijska analiza rezultira većim brojem rješenja. Najprije ističe teorijska i praktična znanja koja mogu uputiti na izbor broja klastera. Nadalje, upućuje na dendrogram u smislu identificiranja velike promjene u udaljenosti na kojoj se klasteri kombiniraju te govori kako i relativna veličina klastera može biti indikativna. Naglašava kako izbor konačnog broja klastera karakterizira subjektivnost istraživača te je stoga potrebno empirijski sud upotpuniti s teorijskim saznanjima koja mogu upućivati na prirodan broj klastera. Broj klastera identificiran je na dendrogramu na temelju kriterija udaljenosti tj. velike promjene u udaljenosti pri kombiniranju klastera. U tom je smislu određena druga najveća promjena udaljenosti na dendrogramu koja je uzeta kao kritična promjena. Druga najveća promjena udaljenosti definira broj klastera na način da se klasterizacija koju ona generira ne smatra zadovoljavajućom, odnosno broj klastera određen je pomicanjem korak u nazad.

Robusnost provedene hijerarhijske klaster analize Wardovom metodom s kvadriranim euklidskim udaljenostima može se preispitati korištenjem druge mjere udaljenosti (Halaj i Zochowski, 2009.). U ovom slučaju ispitana je provedbom hijerarhijske klaster analize Wardovom metodom uz primjenu Čebiševljeve udaljenosti te su generirani rezultati uspoređeni. Čebiševljeva udaljenost izražava se kao maksimalna apsolutna razlika između vrijednosti dvaju objekata (Kurnoga Živadinović, 2007.): 


$$
u_{a b}=M A X_{t}\left|A_{t}-B_{t}\right|
$$

Nehijerarhijska $k$-means metoda klaster analize provedena je shodno rezultatima hijerarhijske klaster analize. K-means analiza zahtijeva unaprijed zadan broj klastera, a osnovno joj je obilježje da omogućava objektu kretanje iz jednog u drugi klaster. Proces klasterizacije k-means metodom sastoji se od nekoliko koraka. Najprije se objekti svrstaju u $k$ početnih klastera, a zatim se svaki objekt dodjeljuje klasteru čijoj je sredini najbliži. Nakon što se objekt pridruži klasteru, odnosno napusti klaster, računa se novi centar klastera te se ponovno računaju udaljenosti i provodi pridruživanje. Postupak se ponavlja sve dok se ne ispuni cilj minimizacije varijabilnosti unutar klastera te maksimizacije varijabilnosti između klastera (Rašić Bakarić, 20Io.). Opisana se procedura ponavlja sve dok se ne odaberu centri klastera koji omogućuju grupiranje svih objekata $u k$ klastera, što rezultira najboljom signifikantnošću rezultata ANOVA analize (Lovrinčević et al., 2005.). Za izračun udaljenosti između klastera $k$-means metodom koristi se euklidska udaljenost izračunata iz sredina koje klasteri imaju na dimenzijama udaljenosti.

Udaljenost između dva objekta ili središta klastera je:

$$
D_{i j}=\sqrt{\frac{\sum\left(x_{i}-x_{j}\right)^{2}}{B D}}
$$

gdje je $x_{i}$ vrijednost varijable objekta $i, x_{j}$ vrijednost varijable objekta $j$ te BD broj dimenzija (Rašić Bakarić, 20Io.).

Za razliku od hijerarhijske, nehijerarhijska metoda dozvoljava objektu da napusti klaster i pridruži se drugom klasteru, ukoliko se time bolje zadovoljavaju kriteriji klasterizacije. Iz toga proizlazi stabilnost i pouzdanost rezultata kao osnovna prednost hijerarhijske metode (Rašić Bakarić, 20Io.). Osim toga, hijerarhijska metoda omogućava analizu većeg broja podataka te veću preciznost budući je dana polazna točka. Nedostatak je manja fleksibilnost u smislu ograničenja mogućnosti primjene različitih mjera udaljenosti te je ponekad teško a priori određivanje broja klastera (Kurnoga Živadinović, 2007.). Kombinacijom dviju metoda dobivaju se najbolji rezultati. U tom kontekstu hijerarhijskom metodom najprije se odredi broj klastera i netipične vrijednosti, a zatim se nakon uklanjanja netipičnih vrijednosti provodi k-means analiza (Rašić Bakarić, 20Io.). Ovaj je pristup korišten u radu.

\section{REZULTATII ISTRAŽIVANJA I RASPRAVA}

Hijerarhijska i nehijerarhijska klaster analiza provedena je u programskom alatu SPSS. Hijerarhijska klaster analiza provedena je na dvije skupine podataka od kojih je jedna skupina dobivena izostavljanjem jedne jedinice promatranja iz druge skupine, odnosno jedna skupina podataka uključuje svih 2I županiju, dok je iz druge isključen Grad Zagreb. U prvom testiranju s uključenim Gradom Zagrebom hijerarhijska klaster analiza primjenom Wardove metode s kvadriranim euklidskim udaljenostima izdvojila je Grad Zagreb u zaseban klaster i netipičnu vrijednost u svim skupinama pokazatelja osim skupine pokazatelja depozitna politika gdje Grad Zagreb formira isti klaster s Istarskom županijom. Slijedom navedenog, u tablici 2. su prikazani rezultati drugog testiranja klaster analize bez Grada Zagreba za sve skupine pokazatelja, osim u slučaju depozitne politike gdje je Grad Zagreb ostao uključen. Prema cut off vrijednosti temeljenoj na drugoj najvećoj promjeni udaljenosti prihvatljivo je klastersko rješenje s tri klastera za sve skupine pokazatelja. 


\section{TABLICA 2.}

Pripadnost županija klasterima prema hijerarhijskoj klaster analizi

\begin{tabular}{|c|c|c|c|c|}
\hline \multirow{2}{*}{ Klaster } & \multicolumn{4}{|c|}{ Županija } \\
\hline & $\begin{array}{l}\text { Ekonomsko } \\
\text { okruženje }\end{array}$ & $\begin{array}{l}\text { Financijska razvijenost } \\
\text { i infrastruktura }\end{array}$ & $\begin{array}{l}\text { Depozitna } \\
\text { politika }\end{array}$ & $\begin{array}{l}\text { Kreditna } \\
\text { politika }\end{array}$ \\
\hline \multirow{10}{*}{ I. } & Bjelovarsko-bilogorska & Bjelovarsko-bilogorska & Dubrovačko-neretvanska & Karlovačka \\
\hline & Brodsko-posavska & Karlovačka & Karlovačka & Koprivničko-križevačka \\
\hline & Osječko-baranjska & Krapinsko-zagorska & Ličko-senjska & Ličko-senjska \\
\hline & Požeško-slavonska & Koprivničko-križevačka & Međimurska & Sisačko-moslavačka \\
\hline & Sisačko-moslavačka & Međimurska & Primorsko-goranska & Splitsko-dalmatinska \\
\hline & Virovitičko-podravska & Osječko-baranjska & Splitsko-dalmatinska & \\
\hline & Vukovarsko-srijemska & Požeško-slavonska & Šibensko-kninska & \\
\hline & & Sisačko-moslavačka & Zadarska & \\
\hline & & Varaždinska & & \\
\hline & & Virovitičko-podravska & & \\
\hline \multirow{7}{*}{ II. } & Krapinsko-zagorska & Brodsko-posavska & Grad Zagreb & Brodsko-posavska \\
\hline & Međimurska & Vukovarsko-srijemska & Istarska & Krapinsko-zagorska \\
\hline & Varaždinska & & & Međimurska \\
\hline & & & & Šibensko-kninska \\
\hline & & & & Varaždinska \\
\hline & & & & Vukovarsko-srijemska \\
\hline & & & & Virovitičko-podravska \\
\hline \multirow{11}{*}{ III. } & Dubrovačko-neretvanska & Dubrovačko-neretvanska & Bjelovarsko-bilogorska & Bjelovarsko-bilogorska \\
\hline & Istarska & Istarska & Brodsko-posavska & Dubrovačko-neretvanska \\
\hline & Karlovačka & Ličko-senjska & Koprivničko-križevačka & Istarska \\
\hline & Koprivničko-križevačka & Primorsko-goranska & Krapinsko-zagorska & Osječko-baranjska \\
\hline & Ličko-senjska & Splitsko-dalmatinska & Osječko-baranjska & Požeško-slavonska \\
\hline & Primorsko-goranska & Šibensko-kninska & Požeško-slavonska & Primorsko-goranska \\
\hline & Splitsko-dalmatinska & Zadarska & Sisačko-moslavačka & Zadarska \\
\hline & Šibensko-kninska & Zagrebačka & Varaždinska & Zagrebačka \\
\hline & Zadarska & & Virovitičko-podravska & \\
\hline & Zagrebačka & & Vukovarsko-srijemska & \\
\hline & & & Zagrebačka & \\
\hline
\end{tabular}

Napomena: rezultati za skupinu pokazatelja depozitna politika uključuju Grad Zagreb, dok je za ostale skupine pokazatelja Grad Zagreb isključen.

Izvor: izrada autora.

Pri ispitivanju robusnosti hijerarhijske klaster analize primjenom Wardove metode s kvadriranim euklidskim udaljenostima dobiveni su zadovoljavajući rezultati. Za skupinu pokazatelja ekonomskog okruženja rješenje s tri klastera dijelom je dovedeno u pitanje budući da su Wardovom metodom uz primjenu Čebiševljeve mjere udaljenosti uz kriterij druge najveće promjene udaljenosti s dendrograma identificirana četiri klastera. Prvi klaster testiranjem je potpuno potvrđen, drugom je dodan tek jedan novi član, a treći klaster razdvojen je $\mathrm{u}$ dva manja. Klasteri formirani u skupini pokazatelja financijske razvijenosti i infrastrukture u potpunosti su potvrđeni testom. Klasterizacija Čebiševljevom udaljenošću potvrdila je u potpunosti dobiveni broj klastera te $75 \%$ pripadnosti županija klasterima prema karakteristikama depozitne politike. Pri ispitivanju robusnosti grupiranja 
na skupini pokazatelja kreditne politike, potvrđena su tri klastera, s odstupanjem pripadnosti klasterima za samo dvije županije, odnosno Io\%.

Nalazi hijerarhijske klaster analize $\mathrm{u}$ dijelu broja klastera i netipičnih vrijednosti korišteni su u oblikovanju nehijerarhijske $k$-means klaster analize. Nehijerarhijska $k$-means analiza provedena je na svim skupinama pokazatelja za tri klastera, a Grad Zagreb, kao netipična vrijednost, isključen je iz analize kod svih skupina pokazatelja, osim depozitne politike. Proces klasterizacije $k$-means metodom izvršen je kroz dvije iteracije za skupine pokazatelja ekonomskog okruženja i karakteristika depozitne politike, dok je grupiranje u skupini pokazatelja kreditne politike generirano kroz tri, a u skupini pokazatelja financijske razvijenosti i infrastrukture kroz pet iteracija. Provedena analiza klasificiranja hrvatskih županija u tri klastera nehijerarhijskom k-means metodom dala je rezultate pripadnosti županija klasterima u tablici 3. i detaljniji prikaz u ANOVA tablici u prilogu.

U skupini pokazatelja ekonomsko okruženje pokazatelj koji najviše doprinosi klasterskom rješenju, s najvišim F omjerom je stopa nezaposlenosti. Svi su pokazatelji signifikantni na rani signifikantnosti $5 \%$ osim pokazatelja stanovništvo. U skupini pokazatelja financijska razvijenost i infrastruktura pokazatelji broj stanovnika na jednu poslovnicu i broj bankomata na jednu poslovnicu najviše doprinose klasterskom rješenju, a varijable neto imovina/BDP i investicije $u$ novu dugotrajnu imovinu namijenjenu financijskoj djelatnosti nisu signifikantne na razini signifikantnosti od 5\%, odnosno IO\%. Skupina pokazatelja depozitna politika u najvećoj je mjeri određena pokazateljem depoziti po stanovniku, premda svi pokazatelji imaju visok F omjer, stoga se klasteri međusobno signifikantno razlikuju. Za skupinu pokazatelja kreditna politika klasterskom rješenju najviše pridonose udio loših kredita u ukupnim kreditima i udio kredita u CHF u ukupnim kreditima. Varijabla udio kredita u EUR u ukupnim kreditima nije signifikantna na razini signifikantnosti od 5\%, a varijabla udio kredita kućanstvima u ukupnim kreditima niti uz IO\%-tnu razinu značajnosti. Moguće je objašnjenje veća raznolikost među županijama, što se uočava i s dendrograma hijerarhijske klaster analize gdje su treća, pa čak i četvrta i peta najveća promjena udaljenosti još uvijek relativno velike.

Usporedbom rezultata primjenom hijerarhijske i nehijerarhijske $k$-means klaster analize prikazanih $u$ tablicama 2 i 3 zaključuje se o djelomičnom podudaranju rezultata. Potpuna podudarnost prisutna je kod skupine pokazatelja financijska razvijenost i infrastruktura kod trećeg klastera te skupine pokazatelja depozitna politika u dijelu klastera kojeg čini Grad Zagreb i Istarska županija. U svim skupinama pokazatelja i formiranim pokazateljima nalaze se preklapanja, međutim klasteri se razlikuju u broju pripadajućih županija i strukturi. Kako je u metodologiji istraživanja hijerarhijska klaster analiza primarno korištena za odabir broja klastera za nehijerarhijsku $k$-means metodu i utvrđivanje netipičnih vrijednosti (prema Rašić Bakarić, 20Io.) u ekonomskoj interpretaciji rezultata prevladavajući značaj imat će rezultati i klasterska rješenja temeljem $k$-means metode. 


\section{TABLICA 3.}

Pripadnost županija klasterima prema nehijerarhijskoj k-means klaster analizi

Županija

\begin{tabular}{|c|c|c|c|c|}
\hline Klaster & $\begin{array}{l}\text { Ekonomsko } \\
\text { okruženje }\end{array}$ & $\begin{array}{l}\text { Financijska razvijenost } \\
\text { i infrastruktura }\end{array}$ & $\begin{array}{l}\text { Depozitna } \\
\text { politika }\end{array}$ & $\begin{array}{l}\text { Kreditna } \\
\text { politika }\end{array}$ \\
\hline \multirow{11}{*}{ I. } & Dubrovačko-neretvanska & Koprivničko-križevačka & Grad Zagreb & Bjelovarsko-bilogorska \\
\hline & Istarska & Međimurska & Istarska & Karlovačka \\
\hline & Primorsko-goranska & Osječko-baranjska & & Koprivničko-križevačka \\
\hline & Splitsko-dalmatinska & Požeško-slavonska & & Ličko-senjska \\
\hline & Zadarska & Varaždinska & & Osječko-baranjska \\
\hline & & Virovitičko-podravska & & Primorsko-goranska \\
\hline & & & & Sisačko-moslavačka \\
\hline & & & & Splitsko-dalmatinska \\
\hline & & & & Varaždinska \\
\hline & & & & Zadarska \\
\hline & & & & Zagrebačka \\
\hline \multirow{9}{*}{ II. } & Bjelovarsko-bilogorska & Bjelovarsko-bilogorska & Bjelovarsko-bilogorska & Brodsko-posavska \\
\hline & Brodsko-posavska & Brodsko-posavska & Koprivničko-križevačka & Krapinsko-zagorska \\
\hline & Karlovačka & Karlovačka & Krapinsko-zagorska & Međimurska \\
\hline & Osječko-baranjska & Krapinsko-zagorska & Osječko-baranjska & Šibensko-kninska \\
\hline & Požeško-slavonska & Sisačko-moslavačka & Sisačko-moslavačka & Virovitičko-podravska \\
\hline & Sisačko-moslavačka & Vukovarsko-srijemska & Varaždinska & Vukovarsko-srijemska \\
\hline & Šibensko-kninska & & Virovitičko-podravska & \\
\hline & Virovitičko-podravska & & Vukovarsko-srijemska & \\
\hline & Vukovarsko-srijemska & & & \\
\hline \multirow{11}{*}{ III. } & Koprivničko-križevačka & Dubrovačko-neretvanska & Brodsko-posavska & Dubrovačko-neretvanska \\
\hline & Krapinsko-zagorska & Istarska & Dubrovačko-neretvanska & Istarska \\
\hline & Ličko-senjska & Ličko-senjska & Karlovačka & Požeško-slavonska \\
\hline & Međimurska & Primorsko-goranska & Ličko-senjska & \\
\hline & Varaždinska & Splitsko-dalmatinska & Međimurska & \\
\hline & Zagrebačka & Šibensko-kninska & Požeško-slavonska & \\
\hline & & Zadarska & Primorsko-goranska & \\
\hline & & Zagrebačka & Splitsko-dalmatinska & \\
\hline & & & Šibensko-kninska & \\
\hline & & & Zadarska & \\
\hline & & & Zagrebačka & \\
\hline
\end{tabular}

Napomena: rezultati za skupinu pokazatelja depozitna politika uključuju Grad Zagreb, dokje za ostale skupine pokazatelja Grad Zagreb isključen. Izvor: izrada autora.

Slijedom provedene analize mogu se diskutirati sljedeća ekonomska i financijska tumačenja rezultata:

- Grad Zagreb izdvaja se kao netipična vrijednost i najrazvijenija uža teritorijalna jedinica Hrvatske po svim pokazateljima. Tek u grupi pokazatelja depozitna politika formira klastersko rješenje zajedno s Istarskom županijom. Razlozi za to su u ekonomskoj snazi Grada Zagreba, ali i prvenstveno strukturi bankovnog sektora i sjedištima banaka koja su dominantno u Gradu Zagrebu, a regionalna sjedišta banaka su rijetka. Time Grad Zagreb u bankovnom poslovanju 
obavlja i čitav niz dodatnih financijskih usluga, dok je poslovanje banaka na ostalim teritorijalnim jedinicama u pravilu svedeno na depozitno-kreditno poslovanje.

- Dubrovačko-neretvanska, Istarska, Primorsko-goranska, Splitsko-dalmatinska i Zadarska županija generalno se mogu okarakterizirati kao razvijene županije kako s grupe pokazatelja ekonomskog okruženja, tako i ostalih financijskih grupa pokazatelja. Ove županije karakterizira, s aspekta financijskog posredovanja, dobra razvijenost financijske infrastrukture, omjer kredita i depozita niži od jedan, viši udjel deviznih depozita u ukupnim depozitima nego u ostalim županijama te viši udio kredita u CHF u ukupnim kreditima, dok se ne ističu veća odstupanja u dijelu kvalitete kreditnog portfelja i sektorske strukture kredita u odnosu na ostale županije. Viši udjel kredita u CHF se može povezati s gospodarskim ciklusom $\mathrm{u}$ Hrvatskoj i rastom stambene izgradnje u godinama prije financijske krize, a u nastupu i razvoju financijske i ekonomske krize s udjelom loših kredita u ovim županijama.

- Nerazvijene županije po ekonomskim obilježjima, kao i stupnju financijske razvijenosti i infrastrukture generalno karakterizira viši omjer kredita i depozita, viši udjel loših kredita u ukupnim kreditima, niži iznos depozita po stanovniku i lošija financijska infrastruktura i razvijenost. Ovi nalazi u skladu su i s nalazima međunarodnih istraživanja (Burgstaller, 20I3.), a nameću i potrebu daljnjeg preispitivanja utjecaja kreditne politike banaka i priljeva financijskih sredstva u nerazvijene županije te posljedičnog eventualnog utjecaja na ekonomski rast. Otvaraju i zanimljivu dimenziju poslovanja banaka u Hrvatskoj koja pokazuje kako banke ipak ne zaobilaze nerazvijene županije, već se u njih ulažu i prilijevaju dodatna sredstva iznad prikupljene depozitne osnovice u toj županiji. Navedeno je u suprotnosti s nekim istraživanjima (Dow, 1987a) o odljevu financijskih sredstava iz periferije u sjedišta banaka, kao i prevladavajućim javnim mnijenjem u Hrvatskoj. Navedeno je potrebno dodatno preispitati uključujući i dodatne varijable i pokazatelje.

- Zajedničke karakteristike bankovnog sustava u dijelu visoke dolarizacije (euroizacije) depozitne i kreditne politike banaka konzistentne su na razini županija.

- Prema rezultatima k-means analize za pojedinačne skupine pokazatelja, klasterima je moguće dati obilježja, prema županijama koje predstavljaju, na razvijene, srednje razvijene i nerazvijene. Ipak, županije se u svim skupinama pokazatelja ne uključuju uvijek u klaster istog stupnja razvijenosti. Navedeno potvrđuje kako su županije specifične prema promatranim skupinama pokazatelja, što je odraz kako ekonomskog stupnja razvoja županije, demografskih karakteristika, strukture gospodarstva pa do usmjerene bankovne poslovne politike i različitih tržišnih potencijala, što je izraženo $u$ skupini pokazatelja financijska razvijenost i infrastruktura. Nalaz potencira važnost provođenja daljnjih užih i usmjerenih istraživanja.

- Naglašen je disparitet i odstupanje u klasterskim rješenjima i pripadnosti županija pojedinim klasterima za skupine pokazatelja depozitna i kreditna politika.

- Izražena je heterogenost županija prema različitim skupinama pokazatelja što dodatno potencira važnost provođenja daljnjih istraživanja.

- Rezultati ističu potrebu uključivanja podataka o financijskom posredovanju financijskih institucija u redovitu statistiku i objavljivanje te naglašavanja važnosti financijskog posredovanja banaka i ostalih financijskih institucija u regionalnom razvoju.

Potrebno je istaknuti ograničenja i nedostatke provedenog istraživanja. Ona se iščitavaju u sveobuhvatnosti analize i nužnosti provođenja daljnjih specijaliziranih istraživanja, potrebe 
povođenja višegodišnjih analiza, kada to podaci budu omogućavali, kako bi se utvrdila pouzdanost rezultata te potrebu selektiranja dodatnih pokazatelja $u$ cilju potpune analize svih relevantnih čimbenika bankovnog poslovanja po županijama.

\section{ZAKLJUČAK}

U radu su, primjenom hijerarhijske i nehijerarhijske k-means klaster analize, sveobuhvatno preispitane karakteristike financijskog posredovanja banaka na županijama u Hrvatskoj. Rezultati u radu ukazuju na izraženu heterogenost županija prema različitim skupinama pokazatelja od ekonomskog okruženja, financijske razvijenosti i infrastrukture, do karakteristika depozitne i kreditne poslovne politike banaka. Ističu se razlike u prvenstveno karakteristikama financijske razvijenosti $\mathrm{i}$ infrastrukture te depozitne politike između razvijenih i nerazvijenih županija $\mathrm{u}$ Hrvatskoj. Grad Zagreb ističe se kao netipična vrijednost i najrazvijenija uža teritorijalna jedinica po svim skupinama pokazatelja, a županije Dubrovačko-neretvanska, Istarska, Primorsko-goranska, Splitsko-dalmatinska i Zadarska kao razvijenije županije s aspekta financijske intermedijacije, karakterizirane stabilnim i značajnijim depozitnim izvorima sredstava. Rezultati istraživanja ukazuju kako banke u Hrvatskoj ipak ne zaobilaze nerazvijene županije, već se u njih ulažu i prilijevaju dodatna sredstva iznad prikupljene depozitne osnovice u toj županiji, iako ostali indikatori ipak ukazuju na nižu razvijenost financijskog posredovanja. Doprinos rada može se prepoznati u započinjanju vrednovanja bankovnog poslovanja i financijskog posredovanja na razini užih teritorijalnih jedinica. Slijedom čega se mogu izvlačiti zaključci o utjecaju bankovnog poslovanja na ekonomski rast, specifičnoj bankovnoj poslovnoj politici kao i potencijalu pružanja bankovnih usluga na županijskoj razini. Navedeno doprinosi i proširenju rasprave o regionalnoj podjeli i osmišljenoj regionalnoj politici Hrvatske koja između ostalog mora počivati i na učinkovitom financijskom posredovanju banaka.

Također, prikazani rezultati i rasprava potenciraju važnost provođenja daljnjih usmjerenih istraživanja i to: (a) u dijelu preispitivanja specifičnosti kreditne politike banaka i utjecaja na županijska gospodarstva te ekonomski rast, (b) detaljne analize depozitne politike banaka i međuovisnosti o demografskim i gospodarskim karakteristikama županija, (c) preispitivanja problema financijske isključenosti po županijama, kao i (d) pronalaženja poveznice između regionalnih sjedišta banka i učinkovitosti županijskih gospodarstava. Provedeno istraživanje u ovom radu predstavlja jedan od prvih pokušaja prikaza i analize financijskog posredovanja banaka po županijama primjenom klaster analize.

Nadalje, zaključci rada i metodološki pristup može biti koristan bankama u Hrvatskoj u oblikovanju usmjerene regionalne poslovne politike te vrednovanju različitog tržišnog pristupa na pojedinim županijama u Hrvatskoj. Na kraju, banka kao institucija koja ima i karakter javnog dobra jedan je od važnijih kanalizatora učinkovitog postizanja ekonomskog rasta u svim teritorijalnim jedinicama te je stoga nužno uključiti i financijski i bankovni sektor u analize i strategije oblikovanja županijskih strateških okvira. 
PRILOZI

Tablica AI.

Rezultati ANOVA tablice za $k$-means klaster analizu

\begin{tabular}{|c|c|c|c|c|c|c|c|}
\hline \multirow{2}{*}{$\begin{array}{l}\text { Skupina } \\
\text { pokazatelja }\end{array}$} & \multirow[b]{2}{*}{ Pokazatelj } & \multicolumn{2}{|c|}{ Klaster } & \multicolumn{2}{|c|}{ Error } & \multirow[t]{2}{*}{$\mathrm{F}$} & \multirow[t]{2}{*}{ Sig. } \\
\hline & & $\begin{array}{l}\text { Mean } \\
\text { Square }\end{array}$ & df & $\begin{array}{l}\text { Mean } \\
\text { Square }\end{array}$ & $\mathrm{df}$ & & \\
\hline \multirow{4}{*}{$\begin{array}{l}\text { Ekonomsko } \\
\text { okruženje }\end{array}$} & $\begin{array}{l}\text { Bruto domaći proizvod po } \\
\text { stanovniku, u tisućama kuna } \\
\text { (popis stan. 20II.) }\end{array}$ & $\mathrm{I}, 6 \mathrm{I} 4$ & 2 & 0,178 & I7 & 9,065 & 0,002 \\
\hline & Neto plaća, u kunama & 2,432 & 2 & 0,313 & 17 & 7,758 & 0,004 \\
\hline & Stanovništvo, u tisućama & 0,700 & 2 & 0,317 & I7 & 2,206 & O,I4I \\
\hline & Stopa nezaposlenosti, u \% & 5,891 & 2 & 0,272 & I7 & 21,683 & 0,000 \\
\hline \multirow{5}{*}{$\begin{array}{l}\text { Financijska } \\
\text { razvijenost i } \\
\text { infrastruktura }\end{array}$} & Neto imovina/BDP, u \% & o,II9 & 2 & 0,059 & 17 & 2,025 & o,I63 \\
\hline & $\begin{array}{l}\text { Broj stanovnika na i poslovnicu, } \\
\text { u tisućama }\end{array}$ & 7,957 & 2 & 0,288 & I7 & 27,669 & 0,000 \\
\hline & $\begin{array}{l}\text { Broj stanovnika na I bankomat, } \\
\text { u tisućama }\end{array}$ & 5,808 & 2 & 0,203 & 17 & 28,579 & o,ooo \\
\hline & $\begin{array}{l}\text { Imovina banaka per capita, } \\
\text { u tisućama kuna }\end{array}$ & 0,225 & 2 & o,o26 & 17 & 8,587 & o,003 \\
\hline & $\begin{array}{l}\text { Investicije u novu dugotrajnu } \\
\text { imovinu namijenjene financijskoj } \\
\text { djelatnosti i djelatnosti osiguranja, } \\
\text { u tisućama kuna }\end{array}$ & O,OI2 & 2 & O,OI2 & I7 & 0,956 & 0,404 \\
\hline \multirow{3}{*}{$\begin{array}{l}\text { Depozitna } \\
\text { politika }\end{array}$} & Krediti/depoziti & 6,483 & 2 & 0,432 & $\mathrm{I} 8$ & I5,OI9 & 0,000 \\
\hline & $\begin{array}{l}\text { Depoziti po stanovniku, } \\
\text { u tisućama kuna }\end{array}$ & 6,075 & 2 & $\mathrm{O}, 2 \mathrm{I} 4$ & I8 & 28,358 & o,ooo \\
\hline & $\begin{array}{l}\text { Devizni depoziti u ukupnim } \\
\text { depozitima, u \% }\end{array}$ & 6,400 & 2 & 0,255 & I8 & 25,076 & o,ooo \\
\hline \multirow{5}{*}{$\begin{array}{l}\text { Kreditna } \\
\text { politika }\end{array}$} & $\begin{array}{l}\text { Udio loših kredita u ukupnim } \\
\text { kreditima, u \% }\end{array}$ & 4,217 & 2 & O,I87 & I7 & $22,5 \mathrm{I} 7$ & o,ooo \\
\hline & $\begin{array}{l}\text { Udio kredita kućanstvima u } \\
\text { ukupnim kreditima, u \% }\end{array}$ & 0,030 & 2 & 0,300 & I7 & O,IOI & 0,904 \\
\hline & $\begin{array}{l}\text { Udio kredita u EUR u ukupnim } \\
\text { kreditima, u \% }\end{array}$ & 0,792 & 2 & 0,294 & 17 & 2,695 & o,o96 \\
\hline & $\begin{array}{l}\text { Udio stambenih kredita u ukupnim } \\
\text { kreditima stanovništva, u \% }\end{array}$ & $\mathrm{I}, 857$ & 2 & $0,49 \mathrm{I}$ & $\mathrm{I7}$ & 3,780 & 0,044 \\
\hline & $\begin{array}{l}\text { Udio kredita u CHF u ukupnim } \\
\text { kreditima, u \% }\end{array}$ & 4,464 & 2 & 0,228 & I7 & $\mathrm{I} 9,58 \mathrm{I}$ & 0,000 \\
\hline
\end{tabular}

Izvor: izrada autora. 


\section{GRAFIKONAI.}

Dendrogrami za provedenu hijerarhijsku analizu prema skupinama pokazatelja s uključenim Gradom Zagrebom

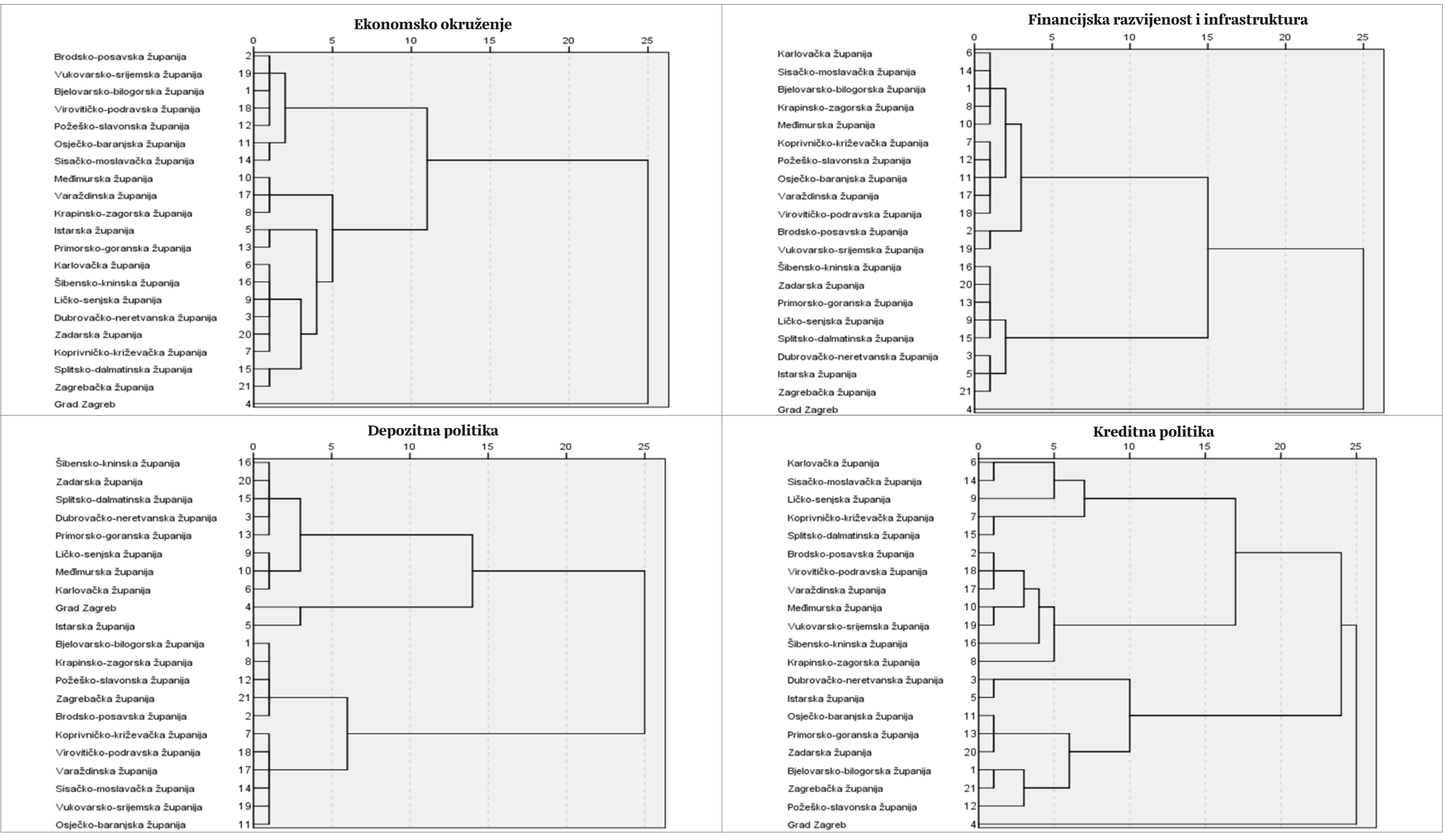

Izvor: izrada autora 


\section{GRAFIKONA2.}

Dendrogrami za provedenu hijerarhijsku analizu prema skupinama pokazatelja bez uključenog Grada Zagreba

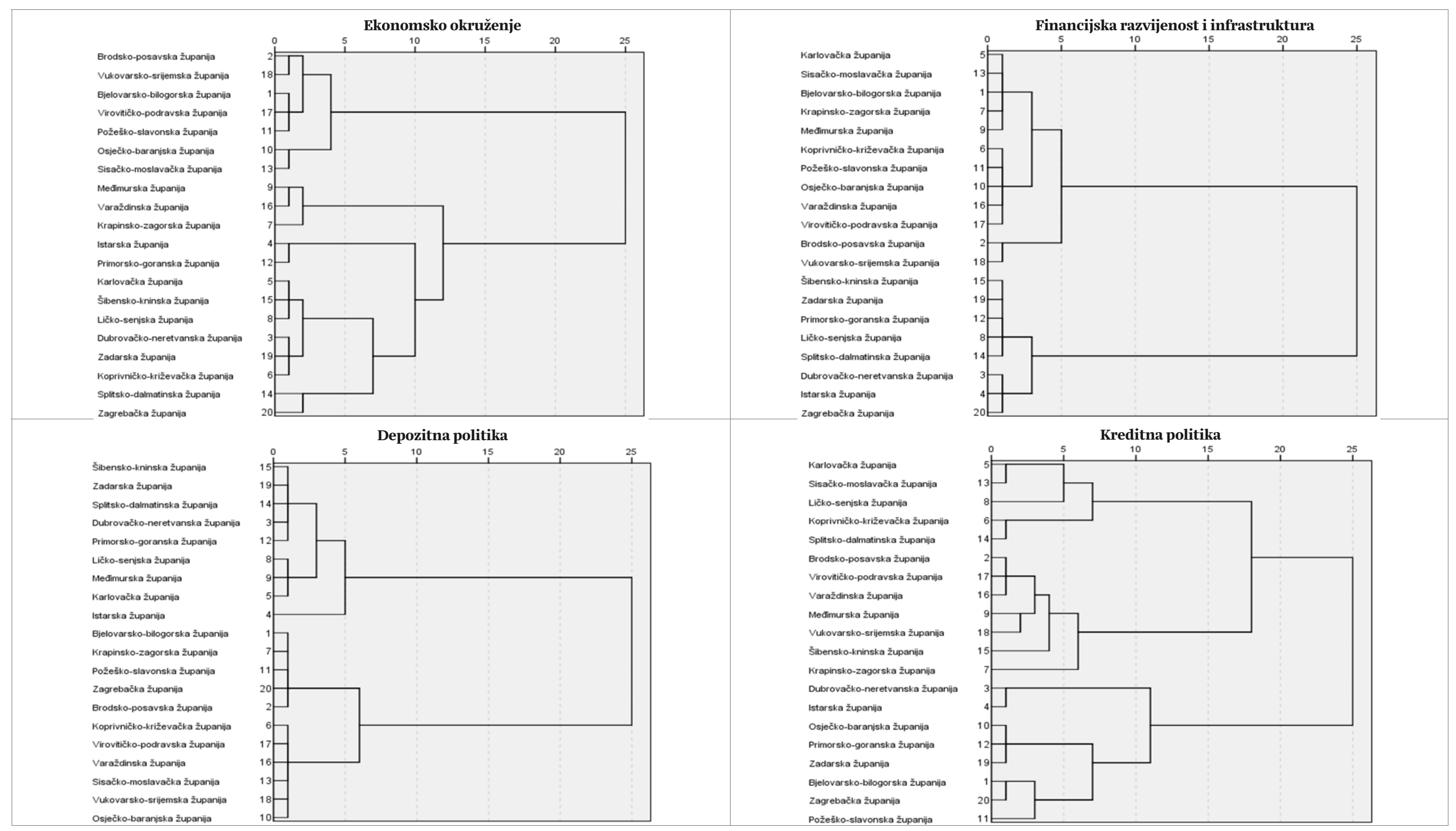




\section{REFERENGE}

I. Allen, F. i Gale, D., 1999. Comparing Financial Systems. Cambridge: MIT Press.

2. Allesandrini, P. [et al.] (ur.), 2009. The Changing Geography of Banking and Finance. Springer.

3. Allesandrini, P. [et al.], 2005. The geography of banking power: the role of functional distance. BNL Quartely Review, 43(235), str. I29-I67.

4. Arestis, P. [et al.], 2005. Financial Structure and Economic Growth. Cepp Working Paper, Br. 06/05.

5. Bađun, M., 2009. Financial intermediation by banks and economic growth: a review of empirical evidence. Financial Theory and Practice, 33(2), str. I2-I52. Dostupno na: 〈http://www.ijf.hr/eng/FTP/2009/2/badjun.pdf>.

6. Baletić, Z. [et al.], I999. Koncepcija regionalnog gospodarskog razvitka Republike Hrvatske. Zagreb: Ekonomski institut.

7. Burgstaller, J., 20I3. Bank Office Outreach, Structure and Performance in Regional Banking Markets. Regional Studies, 47(7), str. II3I-II55. doi: I0.I080/00343404.20II.607809

8. Čavrak, V., 2002. Strategy and Regional Policy Development of Croatia. Ekonomija/Economics, 9(3), str. 645-66I.

9. Čavrak, V., 2003. Sustainable Development of Rural Areas in Croatia. Collection of Papers of the Faculty of Economics and Business Zagreb, $\mathrm{I}(\mathrm{I})$.

IO. Čavrak, V., 20I2. Sustainable Development of Rural Areas in Croatia. Collection of Papers of the Faculty of Economics and Business Zagreb, IO(2).

II. CBS, 20I3. Statistical Yearbook of the Republic of Croatia. Zagreb: CBS.

I2. CBS, 20I4. Gross Domestic Product Data for the Republic of Croatia, NUTS 2 Level and Counties, 20II. First Release, 6o(I2), Br. I2.I.2. Dostupno na: 〈http://www.dzs.hr/Hrv_Eng/publication/2OI4/I2-OI-O2_OI_2OI4.htm. .

I3. CES, 20I4. Labour Market Indicators for Croatia. Dostupno na: 〈http://trzisterada.hzz.hr〉.

I4. CNB, 2OI4. Official data provided at a written request.

15. Colombo, L. V. A. i Turati, G., 20I4. Why do Acquiring Banks in Mergers Concentrate in WellDeveloped Areas? Regional Development and Mergers and Acquisitions (M\&As) in Banking. Regional Studies, 48(2), str. 363-381. doi: I0.1080/00343404.2011.653337

I6. Crocco, M., Figueiredo, A. i Santos, F., 20Io. Differentiated Banking Strategies Across the Territory: an Exploratory Analysis. Journal of Post-Keynesian Economics, 33(I), str.127-150. doi: I0.2753/PKEOI60-3477330107

17. Degryse, H. i Ongena, S., 2005. Distance, Lending Relationships, and Competition. The Journal of Finance, 5O(I).

I8. Demirguc-Kunt, A. i Levine, R., 200I. Financial Structures and Economic Growth: A Cross-Country Comparison of Banks. Markets and Development. Cambridge: MIT Press.

19. Dow, S. C., 1987a. Money and Regional Development. Studies in Political Economy, 23(2), str. 73-74.

20. Dow, S. C., 1992. The Regional Financial Sector: The Scottish Case Study. Regional Studies, 26(7), str. 619-3I. doi: 10.1080/0034340921233134726I

2I. Dow, S.C., I987b. The Treatment of Money in Regional Economics. Journal of Regional Science, 27(I), str. 13-24. doi: IO.IIII/j.I467-9787.I987.tboII4I.X

22. Fernández de Guevara, J. i Maudos, J., 2009. Regional Financial Development and Bank Competition: Effects on Firms' Growth. Regional Studies, 43(2), str. 2II-228. doi: I0.1080/00343400701808907

23. Halaj, G. i Zochowski, D., 2009. Strategic Groups and Banks' Performance. Financial Theory and Practice, 33(2), str. I53-I86. Dostupno na: <http://www.fintp.hr/upload/files/ftp/2009/2/halaj.pdf>.

24. Kurnoga Živadinović, N., 2007. Klasifikacija prostornih jedinica prema stupnju ekonomske razvijenosti. Doktorska disertacija. Zagreb: Ekonomski fakultet.

25. Kurnoga Živadinović, N., 2007. Multivariate Classification of Croatian Counties. Collection of Papers of the Faculty of Economics and Business Zagreb.

26. Leko, V. i Stojanović, A., 20II. Financial Exclusion in: A. Stojanović, and V. Leko. Models of Financing Purposes with Public Interest. Zagreb: Grafit-Gabrijel d.o.o., str. 23-35. 
27. Leko, V., 20II. Financing of Special Purposes with Public Interest u: A. Stojanović, i V. Leko. Models of Financing Purposes with Public Interest. Zagreb: Grafit-Gabrijel d.o.o., str. I-22.

28. Leko, V., 20I2. The Relative Significance of Financial Institutions u: D. Jakovčević i J. Krišto, ur. Insurance Industry in Croatia - Contemporary Changes, New products, Regulation and Risk Management. Zagreb: Grafit-Gabrijel d.o.o., str. 3-I9.

29. Levine, R., 2002. Bank-based or market-based financial systems: which is better? Journal of Financial Intermediation, II(4), str. 398-428. doi: Io.Ioo6/jfin.2002.034I

30. Lovrinčević, Ž. [et al.], 2005. How to Optimally Regionalise Croatia? Economic Review, 56(I2), str. IIO9-II6O.

3I. Puljiz, J., 2009. Factors of Regional Development and Regional Inequalities in Croatia. Doktorska disertacija. Split: Ekonomski fakultet.

32. Rašić Bakarić, I. [et al.], 20I4. The Economic Performance of Croatian Cities - a Statistical Analysis. Economic Review, 65(2), str. II5-I38.

33. Rašić Bakarić, I., 2006. Uncovering Regional Disparities - the Use of Factor and Cluster Analyses. Privredna kretanja i ekonomska politika, I5(IO5), str. 52-76.

34. Rašić Bakarić, I., 20IO. Statistical and Methodological Bases for Definition of Spatial and Economic Entities in the Republic of Croatia. Doktorska disertacija. Zagreb: Ekonomski fakultet.

35. Rašić Bakarić, I., 20I2. A proposal for a new administrative-territorial division of the Republic of Croatia. Economic Research - Ekonomska istraživanja, 25(2), str. 397-4I2.

36. Rodriguez-Fuentes, C. J., 1998. Credit availability and regional development. Papers in Regional Science, $77(\mathrm{I})$, str. 63-75.

37. Valverde, S.C. [et al.], 2007. Financial Innovations in Banking: Impact on Regional Growth. Regional Studies, 4I(3), str. 3II-326. doi: I0.1080/00343400600928350

38. Žuljić, S., 200I. Regionalism and Territorial Structure of Croatia in the Period 1945-200o. Economic Review, 52(I-2), str. 3-28. 